\title{
Optimization with genetic algorithms of chlorogenic acid's extraction and purification from native potato (Solanum tuberosum L.) peel, using an aqueous two-phase system
}

\author{
Doris Inés Paz- Morales \\ Escuela de Ingeniería Agroindustrial. Laboratorio de Biomoléculas. Facultad de Ciencias \\ Agropecuarias. Universidad Nacional de Trujillo \\ Carmen Rosa Rojas-Padilla \\ Departamento de Ciencias Agroindustriales. Laboratorio de Biomoléculas. Facultad de \\ Ciencias Agropecuarias. Universidad Nacional de Trujillo (Perú) \\ Víctor Javier Vásquez-Villalobos* \\ Departamento de Ciencias Agroindustriales. Laboratorio de Biomoléculas. Facultad de \\ Ciencias Agropecuarias. Universidad Nacional de Trujillo (Perú) \\ *Corresponding author. Email: vvasquez@unitru.edu.pe
}

\section{How to Cite}

Paz- Morales, D. I. et al. (2021). Optimization with genetic algorithms of chlorogenic acid's extraction and purification from native potato (Solanum tuberosum L.) peel, using an aqueous two-phase system. Journal of Applied and Natural Science, 13(1): 377 - 384. https://doi.org/10.31018/jans.v13i1.2537

\begin{abstract}
Chlorogenic acid is one of the main phenolic components of potatoes (Solanum tuberosum L.). Researchers have demonstrated that this phenolic compound is a higher concentration in the native Huagalina potato peel and is also found in the whole $u-$ ber's cooking water. This research aims to extract and purify chlorogenic acid (CGA) from potato Huagalina peel obtained from discarded manufacturing for snacks, using an Aqueous Two-Phase System (ATPS). The central composite design rotatable (CDDR); Response Surface Methods (RSM) in R x 64 4.0.3 and RSM package was used to identify the regions of interest that resulted in the best extraction levels. The concentration of ethanol (EtOH) and disodium phosphate (DSP) were selected as factors capable of affecting CGA performance. Extraction efficiency values for concentrations were optimized using genetic algorithms (GA) applying the R package GA. . In the present research, a high value of 0.8 was applied, which produced new "offspring" solutions, which share some good characteristics taken from both parents. The mutation is applied after the crossover, altering some genes in the chains, which was 0.1 . According to what has been reported, the offspring can replace the entire population or replace individuals with less aptitude. This evaluation cycle and selection-reproduction cycle were repeated until a satisfactory recovery of CGA $(97.2 \%)$ estimated with GA at a pH of $3.4\left(25^{\circ} \mathrm{C}\right)$ was achieved, yielding $443.7 \pm 0.062 \mathrm{mg} \mathrm{CGA} \mathrm{/}$ $100 \mathrm{~g}$ dry weight of potato peels.
\end{abstract}

Keywords: ATPS, Chlorogenic acid, Genetic algorithms, Native potato, Potato peels

\section{INTRODUCTION}

Developing countries depend on potatoes as a significant source of food and nutrition, which is why it represents one of the essential Andean crops for both agriculture and food for many rural families (Casas and Daniel, 2017). Currently, Peru is the largest potato producer in Latin America, potatoes being the fourth most important food crop globally (Zhang et al., 2016).

Across the world, potato consumption has changed from fresh to industrial products with added value (Cerón and López, 2013), which generates residues like peel that do not add value to the production chain and are destined for animal feed, fertilizer, and biofuel production (Sandoval et al., 2015). There is high demand throughout the world for snacks made of native processed potatoes. In 2017, Peru recorded an increase of $19.4 \%$ in sales of native potatoes processed products (ADEX, 2016); due to their unique variety of shapes, color, flavors, and textures (Peña, 2017). Peruvian farmers have managed to preserve diversity over many years (Flores, 2017) with breeding programs to improve the nutritional value of the potato in other highlands environments (André et al., .2009 
Research has been carried out with potato peel extract showing its potent antioxidant activity is due to the presence of phenolic compounds such as chlorogenic acid, caffeic acid, and vanillin (Sukrasno and Kusmardiyani, 2014). It has been reported that the polyphenol content in native potatoes is four times higher than in the improved varieties (Morales et al., 2015). Rojas-Padilla and Vásquez-Villalobos (2016) reported for Huagalina peel (mg/ $100 \mathrm{~g}$ dry weight): 476.82, 76.50 and 11.52 for chlorogenic acid, caffeic acid and vanillin respectively; and less concentrations in the cooking water of the whole tuber (Rojas-Padilla et al., 2018).

Numerous studies have examined chlorogenic acid (CGA) biological properties (Tajik et al., 2017), such as antibacterial, antioxidant (Naveed et al., 2018), reducing inflammatory damage (Wang et al., 2020), and anticarcinogenic (Siswanto et al., 2017; Bender and Atalay, 2011). Likewise, preclinical and clinical studies have shown that CGA treatment has beneficial effects on colon cancer, breast tumors, lung cancer, and chronic myelogenous leukemia (Bandyopadhyay et al., 2004).

Due to the importance of CGA, studies have been made of different purification techniques, which offer a high percentage recovery of the final product (DutraMolino et al., 2014). The application of an aqueous twophase system (ATPS) offers advantages such as low cost, short times, and easy recovery of the phaseforming components, which generate a harmless environment for biomolecules due to their low interfacial tension and high water content. (Benavides and RitoPalomares, 2008). It does not represent a health risk, so it may be possible to use it on an industrial scale (Aydogan et al., 2010). This technique involves constructing extractions formed by two polymers, a polymer, a salt, an ionic liquid, a salt, or alcohol of low molecular weight, and salt mixed in a concentration limit, resulting in two immiscible phases (lqbal et al., 2016).

Genetic algorithms (GA) based on the mechanism of natural selection and population genetics constitute a stochastic method to optimize an objective function with linear or non-linear restrictions and are considered very efficient in solving large, discrete, non-linear optimization problems. A clear advantage of using them over other methods is the possibility of finding a general optimal or near-optimal solution without the need to investigate all parameters. GA operates on a population of potential solutions, applying the principle of "survival of the fittest" to increase the chances of a better approximation to a solution. In each generation, a new set of approximations is created by selecting individual parameters according to their aptitude level in the problem domain, using operators from natural genetics (Mariajayaprakash et al., 2015). This research work aimed to use ATPS to extract and purify CGA from potato peel, using disodium phosphate (DSP) and ethanol (EtOH) and optimize CGA extraction by applying GA to create an industrially feasible system.

\section{MATERIALS AND METHODS}

\section{Raw material}

Native potato (Solanum tuberosum L.) variety Huagalina, cultivated in Las Colpas (2,110 m.a.s.I.), Chugay Sánchez Carrión (La Libertad - Peru). Geolocation: $7^{\circ}$ $46^{\prime} 56^{\prime \prime S}$ and $77^{\circ} 52^{\prime} 04^{\prime \prime W}(76 \% \mathrm{RH})$.

\section{Chemical reagents}

Chlorogenic acid (CGA) standard ( $\geq 95 \%$ ) was obtained from Sigma-Aldrich (USA); ethanol absolute $(\mathrm{EtOH})$, ammonium sulfate (AS), and disodium phosphate (DSP) ( $\geq 99 \%$ ); phosphoric acid, acetic acid, boric acid was procured from J.T. Baker; deionized water obtained from a GenPure purification system (TermoFisher Scientific) was used in this study.

\section{Experimental methodology \\ Experimental design}

A Central Composite Design Rotatable (CCDR) was applied with two (2) levels $2^{2}+2^{*} 2+3$ central points. The concentration of ethanol $(\mathrm{EtOH})$ and disodium phosphate (DSP) were selected as factors capable of affecting CGA extraction. Each factor was tested at two levels with limits: upper (+) and lower (-).

Response Surface Methods (RSM) in R x 64 4.0.3 and RSM package was used to identify the regions of interest that resulted in the best extraction levels, which allows more significant degrees of freedom in the ANOVA and the ability to detect curvature in any quadratic effects (Gutiérrez and Vara, 2012). It was based on a $95 \%$ confidence level with a $p$-value $<0.05$ for each treatment. Likewise, it provides adjusted $\mathrm{R}^{2}$ and $\mathrm{R}^{2}$ values and the level of significance of the experimental values with those from the statistical model obtained using RSM.

\section{A sequence of the extraction and purification of CGA using an ATPS \\ Sample preparation}

The native Huagalina variety potatoes were taken to the Laboratory three days after being harvested. They were immediately sliced, freeze-dried (Labconco Free Zone 3.5 Plus), and then the peel was carefully separated from the pulp. The peel was ground, and the powder was stored at $4^{\circ} \mathrm{C}$ for later analysis.

\section{Construction of the phase diagram}

A phase diagram was elaborated by turbidimetric titration using ammonium sulfate (AS) and disodium phosphate (DSP) to compare the system's best formation (Nemati-Knade et al., 2012). To five $\mathrm{mL}$ of ethanol, 0.5 $\mathrm{mL}$ of a $25 \%$ DSP solution was added and then mixed by shaking. It was repeated fifteen times until the data 
to construct the phase diagram was obtained.

\section{Extraction of CGA from potato peel}

The extraction method was adapted from NarváezCuenca et al. (2012). An extraction solution (ES) containing $70 \%$ ethanol was used. Potato peel powder (40 g) was placed in a volumetric flask of $100 \mathrm{~mL}$ and filled up with ES, mixed with a magnetic agitator for $60 \mathrm{sec}$ onds, and given a subsequent ultrasonic treatment (Ultrasonic Bath 3800 ) of $40 \mathrm{~Hz}$ for 60 minutes at $30^{\circ}$ $\mathrm{C}$, then filtered and concentrated using a rotary evaporator (Heidolph WB2000) at $40^{\circ} \mathrm{C}, 1200 \mathrm{rpm}$ and 80 mbar for 40 minutes. The CGA residue was diluted in $100 \mathrm{~mL}$ of deionized water and stored at $4^{\circ} \mathrm{C}$.

\section{Purification of CGA with ATPS}

$0.5 \mathrm{~mL}$ of diluted CGA solution was centrifuged with 5 $\mathrm{mL}$ of deionized water; EtOH and DSP were also added for ATPS optimization.

Once the solution was obtained, $1.5 \mathrm{~mL}$ of BrittonRobinson buffer was added to adjust the $\mathrm{pH}$ to 3.4 at $25{ }^{\circ} \mathrm{C}$, then mixed using a vortex mixer (VWR Analog Vortex Mixer) until the DSP completely dissolved ( 10 $\mathrm{min})$. It was then centrifuged at $3500 \mathrm{rpm}$ for 30 minutes and then kept at $10^{\circ} \mathrm{C}$ for 18 hours, resulting in two phases (Figure 1). The EtOH-rich phase was separated and diluted with $250 \mathrm{~mL}$ deionized water to analyze the CGA concentration using a spectrophotometer (UNICO UV-VIS 4802) (López-Méndez et al., 2014). The absorbance of CGA was measured at a wavelength of $326 \mathrm{~nm}$.

The phase relationship (R) was established using equation (1):

$\mathrm{R}=\mathrm{Vt} / \mathrm{Vb}$

$\mathrm{Vt}$ and $\mathrm{Vb}$ are the volumes of the phase rich in $\mathrm{EtOH}$ and DSP, respectively. The partition coefficient $(\mathrm{K})$ was established using equation (2):

$\mathrm{K}=\mathrm{Ct} / \mathrm{Cb}$

$\mathrm{Ct}$ and $\mathrm{Cb}$ are the CGA concentrations in the $\mathrm{EtOH}$ rich phase and the salt-rich phase.

The extraction efficiency (\% EE) of CGA in the EtOHrich phase was determined using equation (3):

$\% E E=K /((K+1 / R)) \times 100$

\section{Optimization}

The CGA extraction efficiency values for $\mathrm{EtOH}$ and DSP concentrations were optimized through genetic algorithms (GA) applying GA package with the free software $R \times 64$ 4.0.3; the statistical model obtained by RSM was used as an objective function, with the restrictions of the limits established by the coded stationary points of the response surface. A population of 50 individuals with 200 iterations, elitism of 2 , a crossover probability of 0.8 , and mutation probability of 0.1 was used.

\section{RESULTS AND DISCUSSION}

\section{Selecting ethanol/salt system}

In Figure 2, the result of the selection phase is presented, showing two areas delineated by a curve. The upper phase contained mainly supernatant rich in EtOH and CGA, while the lower stage contained an aqueous liquid rich in salt (Cienfuegos et al., 2017). Likewise, it shows disodium phosphate's superposition on ammonium sulfate as the best ethanol/salt ratio for an ATPS (Souza et al., 2015). For this reason, for extraction of CGA in potato peels, ethanol was chosen as a phase former for having advantages such as lower cost, no toxicity, and moderate boiling point, making it suitable for large-scale industrial production (Cienfuegos et al., 2017). Tan et al. (2014) obtained up to $93.44 \%$ efficien-

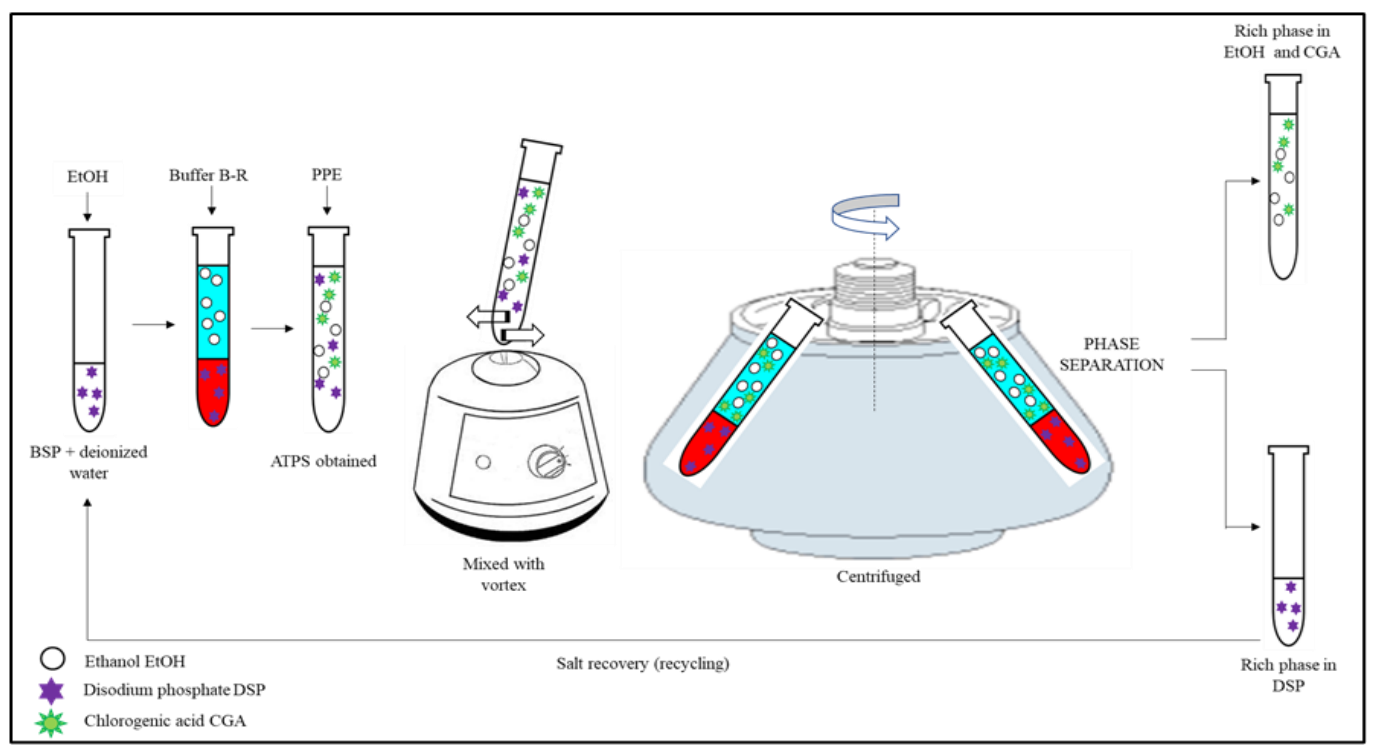

Fig. 1. Sequence of the purification of CGA with an ATPS. 
cy of CGA extraction from ramie (Boehmeria nivea L. Gaud) leaf, using disodium phosphate and $89.91 \%$ ammonium sulfate.; Yang et al. (2016) used an ATPS formed by ionic liquid extract and salt to extract and purify CGA from ramie leaves. The maximum efficiency of $96.18 \%$ was obtained at $\mathrm{pH} 3.0$ and temperature $37{ }^{\circ} \mathrm{C}$. Wang et al.(2017) have used eutectic solvent coupled with the aqueous two-phase system (ATPS) for the negative pressure cavitation extraction and enrichment of chlorogenic acid (CGA) from blueberry leaves. Huang et al.(2019) evaluated hexafluoroisopropanol to develop novel alcohol-salt ATPS, which was applied to extract and purify CGA from ramie leaves. They reported optimum conditions with $\mathrm{pH}$ 3.0. The extraction efficient was $99.3 \%$ in the salt-rich phase. Chong and Su-Ling (2021) evaluated the effects of recycling aqueous two-phase extraction of phenolic components from haskao (Lonicera caerulea) leaves. The total average efficiencies across the two recycling stages were $91.4 \%$ for $\mathrm{EtOH} / \mathrm{AS}$ and $99.6 \%$ for $\mathrm{EtOH} /$ DSP.

Research's novelty is that the extraction and purification of CGA from native potato (Solanum tuberosum L.) peel was done with ATPS, and this method is always reported by researchers to extract and purify CGA in leaves.

The phase diagram data are necessary for designing an ATPS and developing models that may predict the distribution of CGA (López-Méndez et al., 2014). Tan et al. (2014) showed that acid systems formed by EtOH/ DSP ( $\mathrm{pH}$ 3.9) provide a better CGA extraction. Cheng et al. (2017) found that the recovery improved significantly when the mass fractions of DSP increased from $12.70 \%$ to $19.97 \%$, because the water was descended to the lower phase, and a higher concentration of impurities be transferred from the upper to the lower stage; this salt has the sodium $[\mathrm{Na}+]$ cation, the two-phase formation capacity is determined by the anion's hydration capacity.

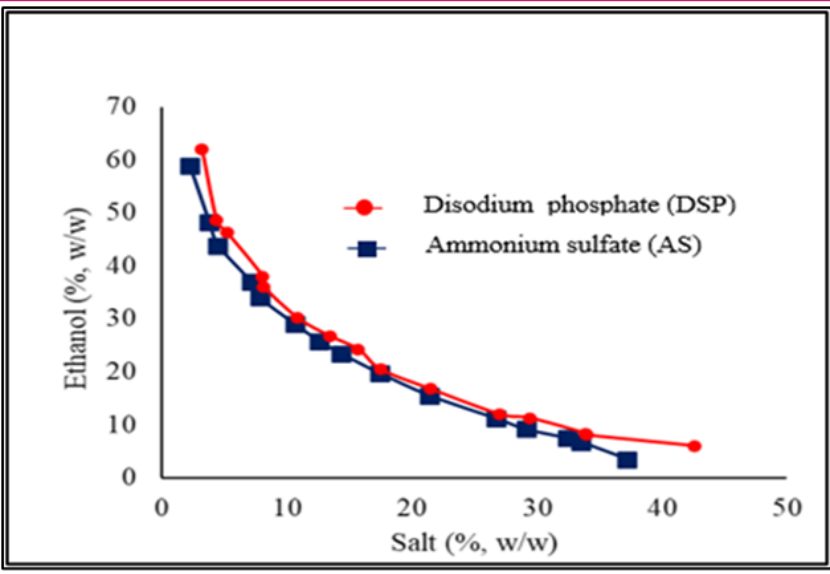

Fig. 2. Ethanol/salt phase diagram.

Cheng et al. (2017) found that the recovery improved significantly when the mass fractions of DSP increased from $12.70 \%$ to $19.97 \%$, because the water was descended to the lower phase, and a higher concentration of impurities be transferred from the upper to the lower stage; this salt has the sodium $[\mathrm{Na}+]$ cation, the twophase formation capacity is determined by the anion's hydration capacity.

Some of the properties that directly affect the particles' partition (ethanol/salt) are temperature, $\mathrm{pH}$, types of salts, concentration, and molecular weight (Mu et al.,

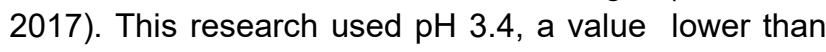
those reported (3.52-3.82) by Wu et al. (2014) with DSP solution.

\section{GA optimization of CGA extraction and purification using ATPS}

Table 1 shows the relationship of $\mathrm{EtOH}$ and DSP on the extraction efficiency through an ATPS, obtaining the highest yield values at $94.93 \%$ and $93.18 \%$ in treatments 3 and 8 , respectively, which contain the highest levels of DSP, and would indicate that when an increase in their concentration occurs, the efficiency of extraction of phenolic compounds increases (Soto-

Table 1. Experimental results of the partition coefficient $(K)$ and extraction efficiency in ATPS.

\begin{tabular}{lllll}
\hline \multirow{2}{*}{ Tests } & Extraction conditions & & Partition coefficient & $\begin{array}{l}\text { Extraction } \\
\text { efficiency }\end{array}$ \\
\cline { 2 - 5 } & $\mathbf{X}_{\mathbf{1}}$, EtOH (\% w/w) & $\mathbf{X}_{\mathbf{2}}$, DSP (\% w/w) & $\mathbf{K}$ & $\mathbf{( \% \text { E.E.) }}$ \\
\hline $\mathbf{1}$ & $-1(16.5)$ & $-1(22.2)$ & $2.98 \pm 0.04$ & $82.26 \pm 0.10$ \\
$\mathbf{2}$ & $1(23.5)$ & $-1(22.2)$ & $2.56 \pm 0.07$ & $84.74 \pm 0.14$ \\
$\mathbf{3}$ & $-1(16.5)$ & $1(32.8)$ & $6.73 \pm 0.09$ & $94.93 \pm 0.08$ \\
$\mathbf{4}$ & $1(23.5)$ & $1(32.8)$ & $2.02 \pm 0.07$ & $83.86 \pm 0.05$ \\
$\mathbf{5}$ & $-1.41(15.05)$ & $0(27.5)$ & $5.75 \pm 0.05$ & $91.41 \pm 0.08$ \\
$\mathbf{6}$ & $1.41(24.95)$ & $0(27.5)$ & $1.43 \pm 0.05$ & $79.62 \pm 0.11$ \\
$\mathbf{7}$ & $0(20)$ & $-1.41(20)$ & $4.09 \pm 0.04$ & $86.81 \pm 0.12$ \\
$\mathbf{8}$ & $0(20)$ & $1.41(35)$ & $4.38 \pm 0.11$ & $93.48 \pm 0.09$ \\
$\mathbf{9}$ & $0(20)$ & $0(27.5)$ & $5.22 \pm 0.05$ & $93.36 \pm 0.09$ \\
$\mathbf{1 0}$ & $0(20)$ & $0(27.5)$ & $5.21 \pm 0.07$ & $93.04 \pm 0.10$ \\
$\mathbf{1 1}$ & $0(20)$ & $0(27.5)$ & $5.18 \pm 0.11$ & $92.76 \pm 0.11$ \\
\hline
\end{tabular}




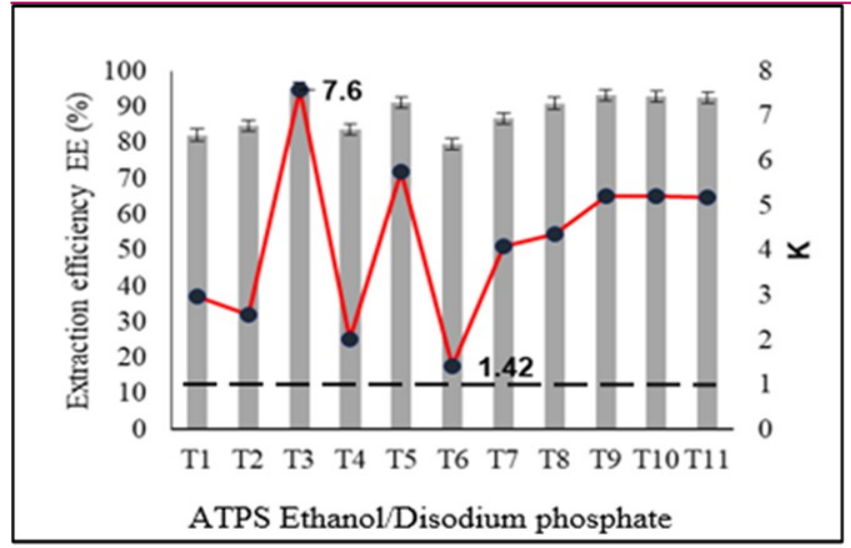

Fig. 3. Extraction efficiency (\% EE, represented by bars) and partition coefficient ( $K$ represented by circles and solid line).

García and Rosales-Castro, 2016). However, the opposite occurs when EtOH's mass fraction increases; the extraction efficiency spirals downwards.

The standard deviations (SD) of the partition coefficient $(\mathrm{K})$ and \% EE were minimal. Treatments 3, 8, 9 showed lower SD than $0.1 \%$.

Figure 3 illustrates the concentration of CGA in ethanolrich phase at different EtOH/DSP concentrations; the highest and lowest value of $\mathrm{K}$ is observed (7.6 and 1.42 , respectively), which is defined as the quotient between the concentrations of the particle in the upper and lower phase of the system.

Higher temperatures are not favorable to induce ATPS's formation; CGA migrates mainly to the alcoholrich phase (Malpiedi, 2014). As a consequence of the ionic interaction between the system and solutes, negative molecules have a higher Partition Coefficient (K) than their neutral equivalent; while, positively charged molecules will have a lower K (Cortés-Burgos, 2008). Table 2 shows the coefficients that determine \% E.E. and establish a second-order statistical model (equation 4).

$Y=93.05333-3.15795^{*} x_{1}+2.65285^{*} x_{2}-3.38750^{*} x_{1}{ }^{*} x_{2}$ $-4.11479^{*} \times 1^{\wedge} 2-1.79979^{*} x_{2}^{\wedge} 2$ Where:

\section{Y: $\quad$ Extraction Efficiency EE (\%)}

$\mathrm{x}_{1}: \quad \mathrm{EtOH}(\%)$ $\mathrm{x}_{2}: \quad \mathrm{DSP}(\%)$

The referred model indicated high values of $R^{2}$ and adjusted $R^{2}$ of 0.956 and 0.9121 , respectively, with a value of $p<0.05$, which confirms an adequate adjustment between the independent variables $x_{1}$ and $x_{2}$ with the \% EE of CGA of native Huagalina variety potato peel. According to Myers et al. (2016), it is possible to build the contour surface and three-dimensional response (Figure 4) and observe the inflection point, which was determined using a genetic algorithm, from the statistical model of equation (4) as an objective function and the stationary points $\mathrm{x}_{1}:-1.121552$ and $\mathrm{x}_{2}$ : 1.792459 obtained by RSM. After 200 iterations, the optimal value of \% EE was $97.2 \%$ (Figure 5).

With a genetic algorithm, the candidate solution is represented by a sequence of chromosomes, simulating traditional genetics (Mariajayaprakash et al., 2015). The chromosome's potential is called the fitness function, which is evaluated by the objective function given by equation (4).

A group of selected chromosomes, called population, was determined to be 50, and based on this, 200 generations were produced, which, according to Figure 5, were sufficient.

In each generation, a new population is formed through genetic operations such as selection, crossing, and mutation. Individuals with high fitness have the opportunity to reproduce by exchanging part of their genetic information, in a crossing procedure, with other highly fit individuals.

In the present research, a high value of 0.8 was applied, and this produced new "offspring" solutions, which share some good characteristics taken from both parents. The mutation was applied after the crossover, altering some genes in the chains, which was 0.1. According to what has been reported, the offspring can replace the entire population or replace individuals who are less fit. This evaluation cycle and selectionreproduction cycle were repeated until a satisfactory solution was found, $97.2 \%$.

According to Figure 5, an optimal \% E.E. of $97.2 \%$ was obtained with a concentration of EtOH and DSP at $16.07 \%$ and $36.99 \%$, respectively. The highest partition

Table 2. Coefficients of the independent variables and significance of the variables of the statistical model of the \% EE level.

\begin{tabular}{lcccc}
\hline & Estimated value & Standard error & Value t & $\operatorname{Pr}(>\mathbf{I t}(\mathbf{I}$ \\
\hline (Intercept) & 93.05333 & 0.92612 & 100.4766 & $1.851 \mathrm{e}-09^{* * *}$ \\
X $_{1}$, EtOH & -3.15795 & 0.56713 & -5.5683 & $0.002572^{* *}$ \\
X, $_{2}$ DSP & 2.65285 & 0.56713 & 4.6777 & $0.005445^{* *}$ \\
EtOH: DSP & -3.38750 & 0.80204 & -4.2236 & $0.008299^{* *}$ \\
EtOH^2 & -4.11479 & 0.67502 & -6.0958 & $0.001720^{* *}$ \\
DSP^2 & -1.79979 & 0.67502 & -2.6663 & $0.044547^{*}$
\end{tabular}

Significance codes: '***' $0.001,{ }^{\prime * * '} 0.01,{ }^{\prime * \prime} 0.05 ; R^{2}: 0.956$, adjusted $R^{2}: 0.9121$; F-statistic: $21.74,5$ d,f, $p$ - value : 0.002099 

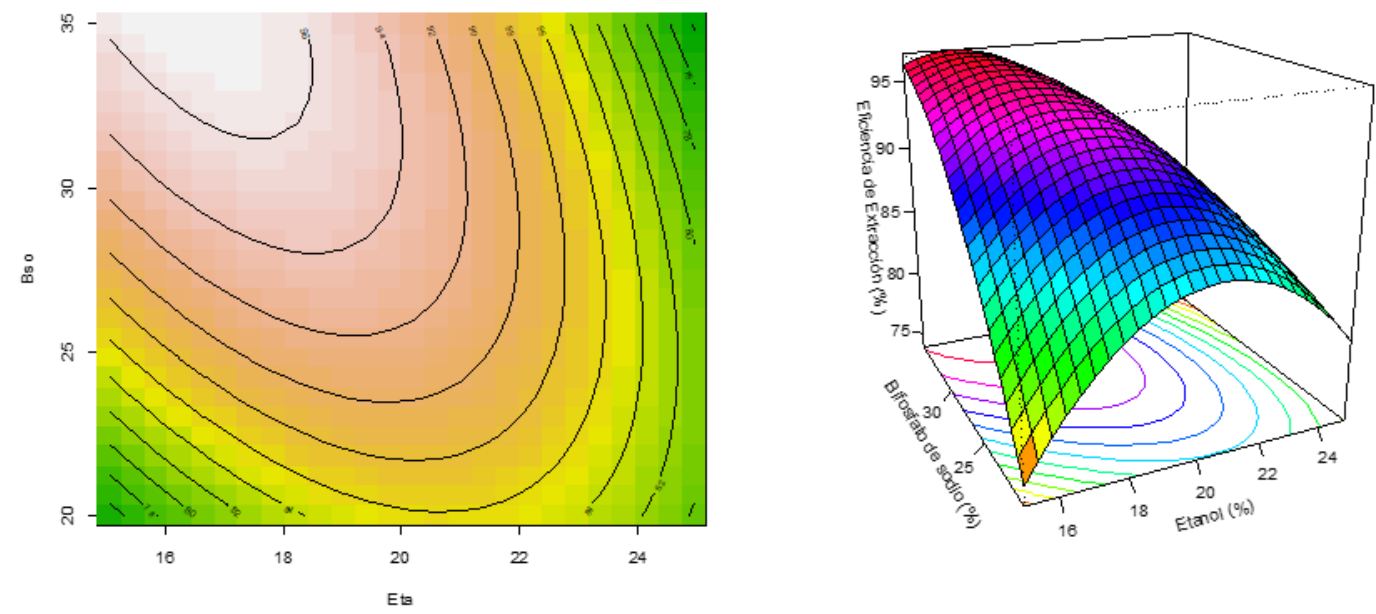

Fig. 4. Contour surface and the three-dimensional response \% EE of CGA.

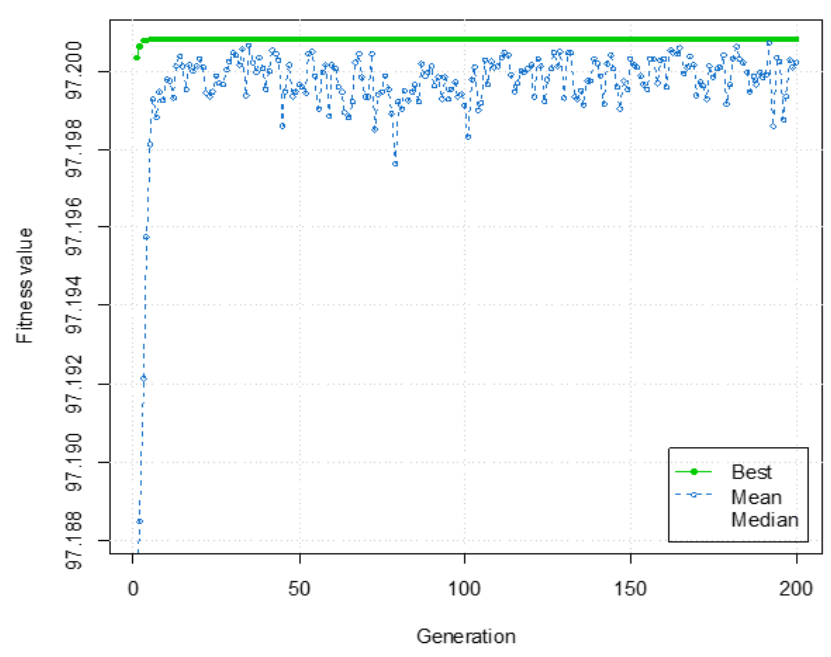

Fig. 5. Iterations to maximize \% E.E. with genetic algorithms.

coefficients and \% E.E. of CGA in the EtOH - rich phase were observed at $25^{\circ} \mathrm{C}$. The Huagalina variety had a yield of $443.7 \pm 0.062 \mathrm{mg}$ CGA / $100 \mathrm{~g}$ peel dry weight; $7 \%$ lower value than those reported by Rojas-Padilla and Vásquez-Villalobos (2016) with 476.82. $\pm 63.58 \mathrm{mg} \mathrm{CGA} / 100 \mathrm{~g}$ peel dry weight, using the UPLC MS-MS method with the same variety of native potato. It shows that the model is adequate, predicting the expected optimization. Therefore, it is shown that the peels of native potato Huagalina constitute an excellent food source with antioxidant potential. This extraction method has all the necessary conditions required to scale up production at an industrial level.

\section{Conclusion}

The extraction and purification conditions of chlorogenic acid (CGA) in the peel of native Huagalina variety potato (Solanum tuberosum L) were optimized. EtOH / DSP was selected as an aqueous two-phase for the extraction system, the best ratio being $16.07 \%$ and $36.99 \%$, respectively. The maximum recovery of CGA was $97.2 \%$ estimated with genetic algorithms under experimental conditions at $25^{\circ} \mathrm{C}$ with a $\mathrm{pH}$ solution of 3.4 , obtaining $443.7 \pm 0.062 \mathrm{mg}$ CGA / $100 \mathrm{~g}$ dry weight of potato peels. The research's novelty is that the extraction and purification of CGA from native potato (Solanum tuberosum L.) peel was done with ATPS; this method has always been reported by researchers, which used for extraction and purification of CGA in leaves.

\section{Conflict of interest}

The authors declare that they have no conflict of interest.

\section{REFERENCES}

1. ADEX. (2016). Asociación de Exportadores. Exportación de papa peruana. http://andina.pe/agencia/noticia.aspx? id $=668919$

2. André, Ch., Oufir, M., Hoffmann, L., Hausman, J., Rogez, H., Larondelle, Y., Evers, D. (2009). Influence of environment and genotype on polyphenol compounds and in vitro antioxidant capacity of native Andean potatoes (Solanum tuberosum L.). Journal of Food Composition and Analysis, 22, 517-524. https://doi.org/10.1016/j.jfca.2008.11.010

3. Aydoğan, Ö., Bayraktar, E., Mehmetoğlu, Ü., Kaeding, T. and Zeng, A. P. (2010). Selection and optimization of an aqueous two-phase system for the recovery of 1,3 , propanediol from fermentation broth. Engineering in Life Sciences, 10(2), 121-129. https://doi.org/10.1002/elsc.20 0900084

4. Bandyopadhyay, G., Biswas, T., Roy, K. C., Mandal, S., Mandal, C., Pal, B. C. and Konar, A. (2004). Chlorogenic acid inhibits Bcr-Abl tyrosine kinase and triggers p38 mitogen-activated protein kinase-dependent apoptosis in chronic myelogenous leukemic cells. Blood, 104(8), 25142522. https://doi.org/10.1182/blood-2003-11-4065

5. Benavides, J. and Rito-Palomares, M. (2008). Aplicación 
Paz- Morales, D. I. et al. / J. Appl. \& Nat. Sci. 13(1): 377 - 384 (2021)

genérica de sistemas de dos fases acuosas polietilenglicol-sal para el desarrollo de procesos de recuperación primaria de compuestos biológicos. Revista Mexicana de Ingeniería Química, 7(2), 99111. http://www.scielo.or g.mx/scielo.php?script=sci_arttext\&pid=S166527 $382008000200002 \&$ Ing $=e s \&$ tIng=es.

6. Bender, O. and Atalay, A. (2021). Polyphenol chlorogenic acid, antioxidant profile, and breast cancer. In Cancer (pp. 311-321). Academic Press. https://doi.org/10.1016/B978-0 $-12-819547-5.00028-6$

7. Casas, P. and Daniel, H. (2017). Análisis de las restricciones que influyen en la competitividad de la cadena productiva de papas nativas (Solanum tuberosum) en la región Apurímac. [tesis de bachiller, Universidad Nacional José María Arguedas]. Repositorio Institucional UNAJMA. http://repositorio.unajma.edu.pe/handle/12345 6789/317

8. Cerón, L. and López, I. (2013). Extracción y cuantificación de compuestos con actividad antioxidante a partir de cáscaras de tres variedades de papa (Solanum tuberosum) en el departamento de Nariño. [Tesis de grado, Universidad de Nariño]. Sistema de Recursos digitales UN. http:// sired.udenar.edu.co/2454/

9. Cheng, Z., Song, H., Cao, X., Shen, Q., Han, D., Zhong, F. and Yang, Y. (2017). Simultaneous extraction and purification of polysaccharides from Gentiana scabra Bunge by microwave-assisted ethanol-salt aqueous two-phase system. Industrial Crops and Products, 102, 75-87. https:// doi.org/10.1016/j.indcrop.2017.03.029

10. Chon, K.Y. and Su-Ling, M. (2021). Effects of recycling on the aqueous two-phase extraction of bioactives from haskap leaves. Separation and Purification Technology, 255, 117755. https://doi.org/10.1016/j.seppur.2020.11 7755

11. Cienfuegos, N. E. C., Santos, P. L., García, A. R., Soares, C. M. F., Lima, A. S. and Souza, R. L. (2017). Integrated process for purification of capsaicin using aqueous twophase systems based on ethanol. Food and Bioproducts Processing, 106, 1-10. https://doi.org/10.101 6/j.fbp.201 7.08.005

12. Cortés-Burgos, M. P. (2008). Predicción del coeficiente de partición de proteínas en sistemas de dos fases acuosas a través de la caracterización bioinformática de su superficie. [tesis de grado, Universidad de Chile]. Repositorio Institucional UC. http://repositorio.uchile.cl/handle/225 0/1 03095

13. Dutra-Molino, J., Feitosa, V. A., de Lencastre-Novaes, L. C., Santos-Ebinuma, V., Lopes A. M., Jozala, A. F., Marques D. de A, V., Pellegrini-Malpiedi, L. and PessoaJúnior, A. (2014). Biomolecules extracted by ATPS: Practical examples. Revista Mexicana de Ingeniería Química, 13(2), 359-377. https://ri.conicet.gov.ar/handle/11 336/ 12064

14. Flores, C. F. (2017). Análisis de los factores que inciden en la baja productividad de 5 variedades de papa nativa en la Provincia de Cotabambas, Región Apurímac [tesis de grado, Universidad Nacional de San Agustín]. Repositorio Institucional UNSA. http://repositorio.unsa.edu.pe/ handle/UNSA/2725

15. Gutiérrez, H. and Vara, R. (2012). Análisis y diseño de experimentos, 2. ${ }^{a}$ ed. Mc Graw Hill, México. https:// gc.scalahed.com/recursos/files/r161r/w19537w/analisi s_y_diseno_experimentos.pdf

16. Huang, A., Deng, W., Wu. D., Wu, S. and Xiao, Y. (2019).
Hexafluorisopropanol-salt aqueous two-phase system for extraction and purification of chlorogenic acid from ramie leaves. Journal of Chromatography A, 1597, 196-201. https://doi.org/10.1016/j.chroma.2019.04.046

17. Iqbal, M., Tao, Y., Xie, S., Zhu, Y., Chen, D., Wang, X. and Hussain, H. I. (2016). Aqueous two-phase system (ATPS): an overview and advances in its applications. Biological procedures online, 18(1), 18. https://doi.or g/10.1186/s12575-016-0048-8

18. López-Méndez, I. C., Ríos, G. and De Sarón, R. (2014). Determinación del contenido de ácido clorogénico por Espectroscopía UV-VIS en hojas secas y verdes de Cecropia peltata (Guarumo) en árboles silvestres de 10, 15, y $20 \mathrm{M}$ de altura en la reserva natural laguna de apoyo [tesis de doctorado, Universidad Nacional Autónoma de Nicaragua, Managua). Repositorio UNAN. https:// repositorio.unan.edu.ni/5369/

19. Malpiedi, L. P., Nerli, B. B., Abdala, D. S., de Alcântara Pessôa-Filho, P. and Pessoa, A. (2014). Aqueous micellar systems containing Triton X-114 and Pichia pastoris fermentation supernatant: $A$ novel alternative for single chain -antibody fragment purification. Separation and Purification Technology, 132, 295-301. https://doi.org/1 0.1016/ j.seppur.2014.05.045

20. Mariajayaprakash, A., Senthilvelan, T. and Gnanadass, R. (2015). Optimization of process parameters through fuzzy logic and genetic algorithm-A case study in a process industry. Applied Soft Computing, 30, 94-103. https:// doi.org/10.1016/j.asoc.2015.01.042

21. Morales, C. A. D., Medina, S. E. L., Salvatierra, C. R. Z., Barrantes, M. Y. R. and Viera, J. P. H. (2015). Cuantificación de los principios anticancerígenos de la variedad de papa nativa de pulpa de color de la región La Libertad con el fin de procesamiento industrial. Pueblo Continente, 24 (2), 425-431. http://journal.upao.edu.pe/Puebl oContinente/article/view/58

22. Mu, T., Sun, H., Zhang, M. and Wang, C. (2017). Sweet potato processing technology. Academic Press, 7(1),357403. https://doi.org/10.1016/B978-0-12-812871-8.00001-5

23. Myers, R ., Montgomery, D., Anderson-Cook (2016) Response Surface Methodology (Process and Product Optimization Using Designed Experiments). Second Edition. John Wiley \& Sons.

24. Narváez-Cuenca, C. E., Vincken, J. P. and Gruppen, H. 2012. Identification and quantification of (dihydro) hydroxycinnamic acids and their conjugates in potato by UHPLC-DAD-ESI-MSn. Food Chemistry, 730-738. https://doi.org/10.1016/j.foodchem.2011.04.050

25. Naveed, M., Hejazi, V., Abbas, M., Kamboh, A. A., Khan, G. J., Shumzaid, M., ... \& XiaoHui, Z. (2018). Chlorogenic acid (CGA): A pharmacological review and call for further research. Biomedicine \& Pharmacotherapy, 97, 67-74. https://doi.org/10.1016/j.biopha.2017.10.064

26. Nemati-Knade, E., Shekaari, H. and Jafari, S. A. (2012). Thermodynamic study of aqueous two-phase systems for some aliphatic alcohols+ sodium thiosulfate+ water. Fluid phase equilibria, 321, 64-72. https://doi.org/10.1016/j.flui d.2012.02.015

27. Peña, E. F. (2017). Extracción y caracterización fisicoquímica y funcional de almidones de cinco variedades de papas nativas procedentes de llave (Puno) [tesis de grado, Universidad Agraria la Molina]. Repositorio Institucio- 
nal UNALM http://repositorio.lamolina.edu.pe/handle/UN ALM/2655

28. Rojas-Padilla, C. and Vásquez-Villalobos, V. (2016). Phenolic compounds with antioxidant capacity of the native Andean potato (Solanum tuberosum L.) Huagalina variety in La Libertad-Peru. Scientia Agropecuaria, 7(3), 333-340. http://dx.doi.org/10.17268/sci.agropecu.201 6.0 3.22.

29. Rojas-Padilla, C, Vásquez-Villalobos, V., Elber, C., Rojas, J. C., Ríos, N. H., Lujan, A. P., Ninaquispe, P. and Espinoza, S. (2018). Phenolic compounds in native potato (Solanum tuberosum L.) cooking water, with potential antioxidant activity. Food Science and Technology, 39 (1), 66-71. https://www.scielo.br/s cielo.php?scrip $\mathrm{t}=\mathrm{sc}$ i_arttext\&pid=S0101-20612019000100066\&tl ng=en

30. Sandoval, M. H., Tenorio-Mucha, J., Tinco-Jayo, A., LoliPonce, R. A. and Calderón-Pinillos, S. (2015). Efecto antioxidante y citoprotector del tocosh de Solanum tuberosum papa en la mucosa gástrica de animales de experimentación. In Anales de la Facultad de Medicina, 76(1), 15 - 20. http://dx.doi.org/10.15381/anales.v76i1.11070

31. Siswanto, F. M., Oguro, A. and Imaoka, S. (2017). Chlorogenic acid modulates hypoxia response of Hep3B cells. Personalized Medicine Universe, 6, 12-16. https:// doi.org/10.1016/j.pmu.2017.03.001

32. Soto-García, M. and Rosales-Castro, M. (2016). Efecto del solvente y de la relación masa/solvente, sobre la extracción de compuestos fenólicos y la capacidad antioxidante de extractos de corteza de Pinus durangensis y Quercus sideroxyla. Maderas. Ciencia y tecnología, 18(4), 701-714. http://dx.doi.org/10.4067/S0718-221X2016 0050 00061

33. Souza, R. L., Lima, R. A., Coutinho, J. A., Soares, C. M. and Lima, Á. S. (2015). Novel aqueous two-phase systems based on tetrahydrofuran and potassium phosphate buffer for purification of lipase. Process Biochemistry, 50 (9),1459-1467. https://doi.org/10.1016/j.procbio.2015.05.015

34. Sukrasno, Y. and Kusmardiyani, S. (2014). Influence of Cooking Methods on Chlorogenic Acid Content of Potato Peels (Solanum tuberosum L.). International Journal of
Pharmacognosy and Phytochemical Research, 6(3), 488491. https://pdfs.semanticscholar.org/626a/eee3249109 23442a5aa2c1a7abe6ede32254.pdf

35. Tan, Z., Wang, C., Yi, Y., Wang, H., Li, M., Zhou, W. and $\mathrm{Li}, \mathrm{F}$. (2014). Extraction and purification of chlorogenic acid from ramie (Boehmeria nivea L. Gaud) leaf using an ethanol/salt aqueous two-phase system. Separation and Purification Technology, 132, 396-400. https://doi.or g/10.1016/j.seppur.2014.05.048

36. Tajik, N., Tajik, M., Mack, I., and Enck, P. (2017). The potential effects of chlorogenic acid, the main phenolic components in coffee, on health: a comprehensive review of the literature. European Journal of Nutrition, 56(7), 22152244. https://doi.org/10.1007/s00394-017-1379-1

37. Wang, D., Tian, L., Lv, H., Pang, Z., Li, ., Yao, Z., \& Wang, S. (2020). Chlorogenic acid prevents acute myocardial infarction in rats by reducing inflammatory damage and oxidative stress. Biomedicine \& Pharmacotherapy, 132, 110773. https://doi.org/10.1016/j.biopha.2020.11 0773

38. Wang,T., Xu, W-J. Wang, S-X., Kou,P., Wang, P.,Wang; $\mathrm{X}-\mathrm{Q}, \mathrm{Fu}, \mathrm{Y}-J .(2017)$. Integrated and sustainable separation of chlorogenic acid from blueberry leaves by deep eutectic solvents coupled with an aqueous two-phase system. food and bioproducts processing, 105, 205-214. https://doi.org/10.1016/j.fbp.2017.07.010

39. Wu, Y., Wang, Y., Zhang, W., Han, J., Liu, Y., Hu, Y. and $\mathrm{Ni}$, L. (2014). Extraction and preliminary purification of anthocyanins from grape juice in an aqueous two-phase system. Separation and Purification Technology, 124, 170 -178. https://doi.org/10.1016/j.seppur.2014.01.025

40. Yang, Z., Tan, Z., Li, F., Li, X. (2016). An effective method for the extraction and purification of chlorogenic acid from ramie (Boehmeria nivea L.) leaves using acidic ionic liquids. Industrial Crops and Products, 89,78-86. http:// dx.doi.org/10.1016/j.indcrop.2016.05.006

41. Zhang, D. Q., Mu, T. H. and Sun, H. N. (2016). Domestic and abroad research progress of potato tuber-specific storage protein patatin. Sci. Agric. Sin, 49, 1746-1756. http:// www.chinaagrisci.com/EN/10.3864/j.issn.0578-175 2.2 